\title{
A literature review of quality in lower gastrointestinal endoscopy from the patient perspective
}

\author{
Maida J Sewitch $\mathrm{PhD}^{1,2}$, Shasha Gong MSc${ }^{2}$, Catherine Dubé MD MSc FRCPC ${ }^{3}$, Alan Barkun MD CM MSc ${ }^{1}$, \\ Robert Hilsden MD PhD FRCPC ${ }^{3}$, David Armstrong MA MB BChir FRCP(UK) FACG AGAF FRCPC ${ }^{4}$
}

\begin{abstract}
MJ Sewitch, S Gong, C Dube, A Barkun, R Hilsden, D Armstrong. A literature review of quality in lower gasstrointestinal endoscopy from the patient perspective. Can J Gastroenterol 2011;25(12):681-685.
\end{abstract}

BACKGROUND: Given the limited state of health care resources, increased demand for colorectal cancer (CRC) screening raises concerns about the quality of endoscopy services. Little is known about quality in colonoscopy and endoscopy from the patient perspective. OBJECTIVE: To systematically review the literature on quality that is relevant to patients who require colonoscopy or endoscopy services. METHODS: A systematic PubMed search was performed on articles that were published between January 2000 and February 2011. Keywords included "colonoscopy" or "sigmoidoscopy" or "endoscopy" AND "quality"; "colonoscopy" or "sigmoidoscopy" or "endoscopy" AND "patient satisfaction" or "willingness to return". The included articles were qualitative and quantitative English language studies regarding aspects of colonoscopy and/or endoscopy services that were evaluated by patients in which data were collected within one year of the colonoscopy/endoscopy procedure.

RESULTS: In total, 28 quantitative studies were identified, of which eight $(28.6 \%)$ met the inclusion criteria (four cross-sectional, three prospective cohort and one single-blinded controlled study). Aspects of quality included comfort, management of pain and anxiety, endoscopy unit staff manner, skills and specialty, procedure and results discussion with the doctor, physical environment, wait times for the appointment and procedure, and discharge. Qualitative studies eliciting the patient perspective on what constituted quality in colonoscopy/ endoscopy were not found.

CONCLUSIONS: Factors related to comfort, staff, communication and the service environment were evaluated from the patient perspective using closed-ended questions that were designed by clinicians and researchers. Future research using qualitative methodology to elicit the patient perspective on quality in colonoscopy and/or endoscopy services is needed.

Key Words: Colonoscopy; Endoscopy; Patient perspective; Quality; Review

$\mathrm{T}$ he number of annual endoscopies performed in Canada has increased dramatically in recent years. In 2004/2005, 408,956 gastroscopies, 155,291 sigmoidoscopies and 602,031 colonoscopies were performed, compared with 492,888 gastroscopies, 132,701 sigmoidoscopies and 969,307 colonoscopies performed in 2008/2009 (1-4). The greatest increase in utilization occurred for colonoscopy, prompted by nationally accepted colorectal cancer (CRC) screening guidelines (5), and recognition of the need for an accurate test to

\section{Une analyse bibliographique de la qualité des endoscopies de la zone gastro-intestinale inférieure selon le point de vue du patient}

HISTORIQUE : Étant donné les effectifs en santé limités, l'augmentation de la demande de dépistage du cancer colorectal (CCR) soulève des inquiétudes quant à la qualité des services d'endoscopie. On ne sait pas grand-chose de la qualité de la coloscopie et de l'endoscopie selon le point de vue des patients.

OBJECTIF : Procéder à une analyse bibliographique systématique de la qualité d'après ce qui est pertinent pour les patients qui ont besoin de services de coloscopie ou d'endoscopie.

MÉTHODOLOGIE : Les auteurs ont effectué une recherche systématique des articles publiés entre janvier 2000 et février 2011 dans PubMed. Les mots-clés étaient colonoscopy ou sigmoidoscopy ouendoscopy ETquality; colonoscopy ou sigmoidoscopy ou endoscopy ET patient satisfaction ou willingness to return. Les articles retenus étaient des études qualitatives et quantitatives de langue anglaise portant sur les aspects des services de coloscopie ou d'endoscopie évalués par les patients, dont les données avaient été colligées dans l'année suivant l'intervention.

RÉSULTATS : Au total, les auteurs ont repéré 28 études quantitatives, dont huit $(28,6 \%)$ respectaient les critères d'inclusion (quatre études transversales, trois études prospectives de cohorte et une étude contrôlée à simple insu). Les aspects liés à la qualité incluaient le confort, la prise en charge de la douleur et de l'anxiété, le savoir-vivre, les compétences et la spécialité du personnel de l'unité d'endoscopie, la discussion avec le médecin au sujet de l'intervention et des résultats, l'environnement physique, les temps d'attente pour obtenir le rendezvous et subir l'intervention, et le congé. Les auteurs n'ont trouvé aucune étude qualitative exposant le point de vue des patients sur ce qui constitue une coloscopie ou une endoscopie de qualité.

CONCLUSIONS : Les auteurs ont évalué les facteurs liés au confort, au personnel, à la communication et au milieu de service selon le point de vue du patient au moyen de questions fermées conçues par des cliniciens et des chercheurs. D'autres recherches s'imposent au moyen d'une méthodologie qualitative afin de connaître le point de vue des patients sur la qualité des services de coloscopie et d'endoscopie.

detect or prevent the progression of CRC. CRC is the third most frequently diagnosed cancer and the second leading cause of cancer death among men and women in Canada (6). CRC screening reduces morbidity and mortality from CRC by removal of precancerous lesions (adenomatous polyps) and by facilitating the treatment of early stage disease $(7-10)$. Colonoscopy is considered to be the optimal CRC screening method, enabling visualization of the entire colon and polyp removal (11-13), and is an integral component of

${ }^{1}$ Department of Medicine, McGill University; ${ }^{2}$ Research Institute of the McGill University Health Centre, Montreal, Quebec; ${ }^{3}$ Departments of Medicine and Community Health Sciences, University of Calgary, Calgary, Alberta; ${ }^{4}$ Division of Gastroenterology, McMaster University Medical Centre, Hamilton, Ontario

Correspondence: Dr Maida J Sewitch, 687 Pine Avenue West, Montreal, Quebec H3A 1A1. Telephone 514-934-1934 ext 44736, fax 514-934-8293, e-mail maida.sewitch@mcgill.ca

Received for publication May 31, 2011. Accepted June 8, 2011 


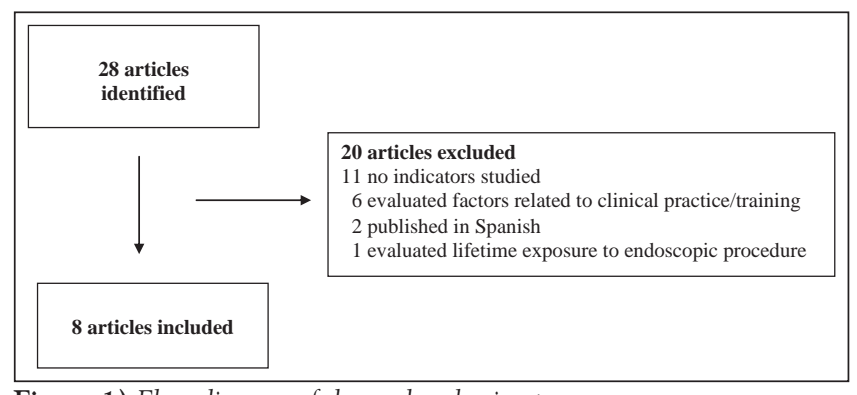

Figure 1) Flow diagram of the study selection process

any CRC screening strategy as either the initial examination or the follow-up examination to positive findings from other screening methods. However, limited resources including endoscopy unit staff, equipment and facilities have raised concerns about the quality of endoscopic services. Moreover, risks that are considered to be reasonable and ethical when diagnostic tests are performed in sick individuals may be neither when the same test is applied to healthy individuals in the context of screening (14).

Patient experience with colonoscopy or endoscopy is important in evaluating both the performance of procedures and the delivery of high-quality care $(15,16)$. A satisfactory endoscopic experience will likely encourage return for follow-up, adherence to periodic screening (17) and positive word-of-mouth communication. It is, therefore, essential to understand the patient perspective on what constitutes quality in colonoscopy/endoscopy to implement tailored improvements, conduct re-evaluations and enhance the current standard of practice and the quality of care.

In the United Kingdom (UK), the Global Rating Scale (GRS) quality assurance program was implemented in 2004. This ongoing program, which is patient-centred and uses the GRS quality assessment tool for gastrointestinal endoscopy services, has successfully motivated individual endoscopy units to evaluate overall service quality in four domains of service provision (eg, clinical quality, quality of patient experience, training and work force), to implement improvement strategies and to re-evaluate these strategies (18). These activities have resulted in improved quality of patient care and service delivery (19). Although Canadian institutions wish to implement the GRS in their endoscopy units, there is uncertainty concerning the relevance of the GRS items in the Canadian health care environment and to the Canadian public.

Therefore, the purpose of the present study was to systematically review the literature on aspects of colonoscopy and endoscopy services that may be considered important to patients, and to determine the rigour with which patients' concerns were identified and characterized.

\section{METHODS}

A PubMed search of articles published between January 2000 and February 2011 was conducted. The keywords used were "colonoscopy" or "sigmoidoscopy" or "endoscopy" AND "quality"; "colonoscopy" or "sigmoidoscopy" or "endoscopy" AND "patient satisfaction" or "willingness to return". Additional articles were retrieved after manual examination of the reference sections of the initial articles.

\section{Inclusion and exclusion criteria}

Studies of any design (eg, cross-sectional, prospective) that were published in English were included if the primary data collection had occurred within one year of the colonoscopy or endoscopy, and factors relating to quality, patient satisfaction with or willingness to return for colonoscopy/endoscopy were perceived or evaluated only by patients. Studies were excluded if factors were evaluated by physicians or persons other than the individual who underwent the procedure, and if the procedure was performed at any point during one's lifetime (to reduce recall bias).

\section{RESULTS}

A total of 28 articles were identified, of which eight (20-27) (28.6\%) were retained for the present review (Figure 1). Characteristics of the eight included studies are summarized in Table 1. Study designs included four cross-sectional studies, three prospective cohort studies and one clinical trial. Two studies were conducted in Canada, two in the United States, and one each in the UK, Italy, Israel and Spain. The percentage of females ranged from $43 \%$ to $57 \%$, and the mean patient age ranged from 55 to 62 years; only two studies specified age inclusion criteria $(20,21)$. Factors associated with patient satisfaction and/or willingness to return included endoscopy unit staff manner, skills and specialty, facility environment, comfort, pain management and pretest anxiety, wait time, and having discussions with the doctor about results and explanation of the procedure

\section{Study methods}

Study methodologies differed in terms of questionnaire format, timing of questionnaire completion and mode of questionnaire administration. Questionnaire formats included 5-point rating scales $(20,22,25$, 27 ) and Likert scales $(21,24,26,27)$, binary 'Yes/No' responses (20) and $100 \mathrm{~mm}$ visual analogue scales (23). In two studies $(20,21)$, the degree of pain during the procedure was assessed using either a 4- or 7-point rating scale. In two studies $(20,27)$, the level of anxiety before and/or during the procedure was assessed using 5 -point rating scales.

The timing of questionnaire completion differed across studies. In five studies $(20,21,23,24,27)$, questionnaires were completed before discharge from the endoscopy units. In seven studies, they were completed within $24 \mathrm{~h}(21,23)$, three days (22), seven days (20), three weeks $(26,27)$ or up to six months $(25)$ following the procedure. In four studies (20-23), questionnaires were distributed to and completed by patients both before and after the procedure.

The mode of questionnaire administration also varied across studies, with investigators using face-to-face interviews $(20,24,25,27)$, telephone interviews $(20,26)$ and mail-back questionnaires $(20-23,27)$ to obtain information on patients' perspectives. Response rates ranged from $54 \%$ to $90 \%$, although three studies $(24,25,27)$ did not provide this information.

\section{Factors influencing patient satisfaction}

Cleanliness, comfort and the physical environment influenced patient satisfaction with colonoscopy and/or endoscopy services $(20,22,24)$. In five studies $(20-23,26)$, several wait times were considered to be important including wait time from initial assessment to the endoscopy appointment, from registration in the endoscopy facility to the procedure and from entry to the recovery room until discharge. In seven studies $(20,22-27)$, endoscopy unit staff influenced patient satisfaction including their manner, skills, specialty, and adequate discussions and/or explanations of the procedure and/or results with the endoscopist. Two studies $(23,27)$ found associations between a higher level of pain score or pretest anxiety and lower patient satisfaction.

\section{Factors influencing patient willingness to return}

Comfort while waiting for the procedure, lack of embarrassment during the procedure, experiencing less discomfort than expected, waiting an acceptable length of time until discharge and discussing the results with the endoscopist following the colonoscopy (22) were associated with greater willingness to return for colonoscopy.

\section{DISCUSSION}

Patient experience is a critical aspect of heath care service delivery. Aiming for a high-quality endoscopy experience enhances the standard of endoscopy and provides data for improving the quality of care. Patients with favourable endoscopy experiences are more likely to comply with medical advice, adhere to screening, maintain relationships with the same care providers and use medical services in the future, whereas patients with poor experiences are more likely to leave their care providers and be less compliant (28). 
TABLE 1

Characteristics of included studies of the factors associated with patient satisfaction and/or willingness to return

\begin{tabular}{|c|c|c|c|c|c|}
\hline \multirow[b]{2}{*}{$\begin{array}{l}\text { Author (reference), } \\
\text { year, country }\end{array}$} & \multirow[b]{2}{*}{ Study design } & \multicolumn{4}{|c|}{ Age inclusion criteria } \\
\hline & & Response rate, \% & $\begin{array}{c}\text { Total, } n \\
\text { (\% female) }\end{array}$ & $\begin{array}{l}\text { Age, years, } \\
\text { mean } \pm S D\end{array}$ & Factors \\
\hline $\begin{array}{l}\text { Ko et al (20), 2009, } \\
\text { Canada }\end{array}$ & $\begin{array}{l}\text { Prospective } \\
\text { cohort }\end{array}$ & $\begin{array}{l}\text { Preprocedure: ? } \\
\text { Immediately postprocedure: } 79 \\
1 \text { week postprocedure: } 54\end{array}$ & $261(47)$ & $\begin{array}{c}\geq 18 \\
55 \pm 14\end{array}$ & $\begin{array}{l}\text { Endoscopy unit staff manner and skills } \\
\text { Physical environment } \\
\text { Discussion of procedure/results with physician } \\
\text { Wait time from initial assessment or } \\
\text { registration to procedure } \\
\text { Discomfort/pain }\end{array}$ \\
\hline $\begin{array}{l}\text { Eckardt et al (21), } \\
2007, \text { USA }\end{array}$ & $\begin{array}{l}\text { Single-blinded } \\
\text { controlled trial }\end{array}$ & $\begin{array}{l}\text { Preprocedure: } 80 \\
\text { Immediately postprocedure: } 80 \\
24 \text { h poststudy: } 75\end{array}$ & $368(43)$ & $\begin{array}{c}\geq 18 \\
56.9 \pm 9.2\end{array}$ & Wait time to beginning of procedure \\
\hline $\begin{array}{l}\text { de Jonge et al (22), } \\
\text { 2010, Canada }\end{array}$ & $\begin{array}{l}\text { Prospective } \\
\text { cohort }\end{array}$ & $\begin{array}{l}\text { Preprocedure: ? } \\
3 \text { days postprocedure: } 71.7\end{array}$ & $1187(57)$ & $\begin{array}{c}\text { NS } \\
55.7 \pm 15\end{array}$ & $\begin{array}{l}\text { Comfort while waiting in the wait area } \\
\text { Wait time until discharge } \\
\text { No embarrassment } \\
\text { Less discomfort than expected } \\
\text { Discussion of results with physician } \\
\text { Younger age }\end{array}$ \\
\hline $\begin{array}{l}\text { Maslekar et al (23), } \\
\text { 2009, United } \\
\text { Kingdom }\end{array}$ & $\begin{array}{l}\text { Prospective } \\
\text { cohort }\end{array}$ & $\begin{array}{l}\text { Preprocedure: ? } \\
\text { Immediately postprocedure: } 89.7 \\
24 \text { h postprocedure: } 81.9\end{array}$ & 503 (NR) & $\begin{array}{l}\text { NS } \\
\text { NR }\end{array}$ & $\begin{array}{l}\text { Discomfort/pain } \\
\text { Endoscopist skills } \\
\text { Wait time for appointment } \\
\text { Pretest anxiety level }\end{array}$ \\
\hline $\begin{array}{l}\text { Scotto et al (24), } \\
2008, \text { Italy }\end{array}$ & Cross sectional & Immediately postprocedure: ? & $200(54)$ & $\begin{array}{l}\text { NS } \\
\text { NR }\end{array}$ & $\begin{array}{l}\text { Cleanliness } \\
\text { Comfortableness of endoscopy room } \\
\text { Information of endoscopic procedures } \\
\text { Explanation of diagnosis } \\
\text { Caring staff }\end{array}$ \\
\hline $\begin{array}{l}\text { Yanai et al (25), } \\
2008, \text { Isreal }\end{array}$ & Cross sectional & Up to 6 months postprocedure: ? & $81(N R)$ & $\begin{array}{l}\text { NS } \\
\text { NR }\end{array}$ & $\begin{array}{l}\text { Explanation of the procedure before and after } \\
\text { by endoscopy unit staff } \\
\text { Immediate results discussion with doctors }\end{array}$ \\
\hline $\begin{array}{l}\text { Del Rio et al (26), } \\
\text { 2007, Spain }\end{array}$ & Cross sectional & Three weeks postprocedure: 83.6 & $537(57)$ & $\begin{array}{c}\text { NS } \\
49 \pm 15\end{array}$ & $\begin{array}{l}\text { Wait time until the appointment } \\
\text { Explanation of procedure }\end{array}$ \\
\hline $\begin{array}{l}\text { Schoen et al (27), } \\
\text { 2000, USA }\end{array}$ & Cross sectional & $\begin{array}{l}\text { Immediately postprocedure: ? } \\
3 \text { to } 4 \text { weeks poststudy: ? }\end{array}$ & $1221(45.5)$ & $\begin{array}{c}\text { NS } \\
61.8 \pm 6.1\end{array}$ & $\begin{array}{l}\text { Pretest anxiety } \\
\text { Specialty of endoscopist }\end{array}$ \\
\hline
\end{tabular}

? Unknown; NR Not reported; NS Not specified

In the present review, we found only quantitative studies of factors that influence patient satisfaction with and the willingness to return for colonoscopy or endoscopy. Patients rated several factors as important to their experience of colonoscopy or endoscopy, including endoscopy unit staff manner, skills and specialty, facility environment, comfort, pain management and pretest anxiety, wait time and adequate discussion with doctors. Ko et al (20) and Scotto et al (24) found that personal manner and technical skills of the endoscopy unit staff were rated to be important by patients and were positively associated with patient satisfaction. In the study by Yacavone et al (29), endoscopist skill was considered to be the most important of 15 questionnaire items. Friendliness of the medical staff topped the list of a 12 -item questionnaire related to operative care developed by Tarazi et al (30), with 67\% of patients rating friendliness as the most important factor. The specialty of the endoscopist could impact patient satisfaction. Schoen et al (27) showed that there were significant differences in patient satisfaction among three endoscopist specialties (nurse practitioner, internist and gastrointestinal specialist); nurse practitioners had satisfaction scores that were similar to those of physicians, whereas procedures that involved trainees had lower overall satisfaction scores. Short wait times and prompt access to endoscopy were also highly valued (20-23). Denis et al (31) showed that $19 \%$ of patients were not satisfied with their colonoscopy experience due to the long wait time for the procedure. De Jonge et al (22) reported that the absence of embarrassment was positively associated with comfort and acceptance of colonoscopy, as well as with the willingness to return for repeat testing.

Control of discomfort and pain during the procedure was considered to be a high priority by patients $(20,22,23,29)$. Inadequate sedation during the procedure was negatively associated with patient satisfaction to the extent that some patients were reluctant to undergo the same procedure again $(28,32)$. In fact, adequate control of discomfort and pain during the procedure was ranked first by $16 \%$ of patients, and was rated the second most important factor overall (29). In the study reported by Maslekar et al (23), pain management was ranked as the most important factor associated with satisfaction by patients who underwent lower gastrointestinal endoscopy (colonoscopy and flexible sigmoidoscopy) and as the third most important factor by endoscopists. Anxiety level before and/or during the procedure was evaluated for its association with patient satisfaction. Maslekar et al (23) and Schoen et al (27) showed that higher levels of pretest anxiety were associated with lower satisfaction scores in patients who underwent colonoscopy and flexible sigmoidoscopy. This finding is consistent with those of Pena et al (33), who showed that procedural anxiety can result in poor endoscopy satisfaction. However, Ko et al (20) demonstrated that anxiety level before and during the procedure cannot be considered as a predictor of satisfaction in patients who undergo endoscopic procedures.

Patients considered communication with their physicians essential to the delivery of high-quality health care $(20,22,24-26)$. Patients were more satisfied when more time was spent discussing the procedure and preliminary results with their physicians. Fox et al (34) showed that women who perceived their physicians as exhibiting high levels of enthusiasm about fecal occult blood testing or mammography during discussions were more likely to undergo screening than those whose physicians exhibited low levels of enthusiasm. Similarly, CarcaiseEdinboro et al (35) showed that patients who spent sufficient time 
with and received adequate explanations from health providers were more likely to be screened for CRC than people who were given less time and had limited discussion with their providers. Lauver et al (36) reported that practitioner communication such as endorsement of, encouragement and assistance with mammography scheduling facilitated the use of mammography.

In reviewing the included studies, it became apparent that knowledge of the patient endoscopy experience was not sought independently of those who conducted the research. In all studies, closed-ended questions were designed based on what clinicians and researchers perceived to be important quality indicators; patients' responses were subsequently used to substantiate these ideas. However, using qualitative methodologies is pivotal when the aim of the research is to understand patients' lived experiences, perspectives and values. Physicians commonly do not understand the patient viewpoint regarding aspects of endoscopy such as adequate sedation (37) and pain (27). Therefore, it is essential that focus groups or interviews be conducted to elicit and explore the patient experience. These focus group or interview discussions could address each phase of the procedure individually (ie, before, during and after), which may help patients recall variables that would be relevant within the context of a patient-centred colonoscopy or endoscopy quality improvement program (38) in which these indicators would be evaluated and monitored.

The present review has both strengths and limitations. One strength was that two of the studies that identified a majority of factors $(20,22)$ were conducted in Canada, thereby capturing Canadian patients' perspectives.

\section{REFERENCES}

1. National Grouping System. Categories Report, Canada 2004-2005. Revised August 2007. Ottawa: Canadian Insitute for Health Information, 2007.

2. National Physician Database. 2008-2009 data release. Ottawa: Canadian Institute for Health Information, 2010.

3. National Physician Database. 2007-2008 data release. Ottawa: Canadian Institute for Health Information, 2009.

4. National Physician Database. 2006-2007 data release. Ottawa: Canadian Institute for Health Information, 2011.

5. Leddin D, Hunt R, Champion M, et al. Canadian Association of Gastroenterology and the Canadian Digestive Health Foundation: Guidelines on colon cancer screening. Can J Gastroenterol 2004;18:93-9.

6. Canadian Cancer Society/National Cancer Institute of Canada. Canadian Cancer Society Statistics 2010, Toronto, Canada 2010. 2010.

7. Winawer SJ, Zauber AG, Ho MN, et al. Prevention of colorectal cancer by colonoscopic polypectomy. The National Polyp Study Workgroup. N Engl J Med 1993;329:1977-81.

8. Atkin WS, Cuzick J, Northover JM, Whynes DK. Prevention of colorectal cancer by once-only sigmoidoscopy. Lancet 1993;341:736-40.

9. Pignone M, Rich M, Teutsch SM, Berg AO, Lohr KN. Screening for colorectal cancer in adults at average risk: A summary of the evidence for the U.S. Preventive Services Task Force. Ann Intern Med 2002;137:132-41.

10. Mandel JS, Church TR, Bond JH, et al. The effect of fecal occult blood screening on the incidence of colorectal cancer. N Engl J Med 2000;343:1603-7.

11. Winawer SJ, Stewart ET, Zauber AG, et al. A comparison of colonoscopy and double-contrast barium enema for surveillance after polypectomy. National Polyp Study Work Group. N Engl J Med 2000;342:1766-72.

12. Feldman GE, McCord CW, Bassett MT, Frieden TR. Screening for colorectal cancer. JAMA 2003;290:191.

13. Lieberman DA, Weiss DG, Bond JH, Ahnen DJ, Garewal H, Chejfec G. Use of colonoscopy to screen asymptomatic adults for colorectal cancer. Veterans Affairs Cooperative Study Group 380. N Engl J Med 2000;343:162-8.

14. Fletcher RH, Fletcher SW. Clinical Epidemiology. The Essentials. Baltimore: Lippincott Williams \& Wilkins, 2005:147-67.

15. Cohen L, Delaney P, Boston P. Listening to the customer: Implementing a patient satisfaction measurement system. Gastroenterol Nurs 1994;17:110-5.

16. Aharony L, Strasser S, Gong. Patient satisfaction: What we know about and what we still need to explore. Med Care Rev 1993;50:49-79.
The review was limited by including only articles published in English, none of which included validated questionnaires. Moreover, studies with low or unreported response rates may have provided findings that were not representative of the populations under study. Furthermore, although five studies included open-ended questionnaire items $(20,22,24,25,27)$, the authors reported either poor response rates to these questions or failed to discuss the findings.

\section{CONCLUSION}

Our literature search of patient quality indicators for endoscopy or colonoscopy services identified only quantitative studies of factors associated with patient satisfaction with and willingness to return for endoscopy or colonoscopy. Our findings showed that the important quality measures were related to endoscopy unit staff, the facility environment, comfort, wait time, pain management, pretest anxiety and patient-physician communication. Qualitative studies that seek the patient perspective independently of clinicians and researchers are needed to advance our understanding of the quality indicators that will be useful in designing endoscopy quality assurance programs.

ACKNOWLEDGEMENTS:This research was supported by an operating grant from the Canadian Digestive Health Foundation. Maida J Sewitch PhD, is a Research Scholar of the Fonds de recherche du Québec - Santé.
17. Chartier L, Arthurs E, Sewitch MJ. Patient satisfaction with colonoscopy: A literature review and pilot study. Can J Gastroenterol 2009;23:203-9.

18. Valori R, Sint Nicolaas J, de Jonge V. Quality assurance of endoscopy in colorectal cancer screening. Best Pract Res Clin Gastroenterol 2010;24:451-464.

19. Valori RM, Barton R, Johnston DK. The English National Endoscopy Quality Assurance Programme: Quality of care improves as waits decline. GIE, 2009;69: AB221.

20. Ko HH, Zhang H, Telford JJ, Enns R. Factors influencing patient satisfaction when undergoing endoscopic procedures. Gastrointest Endosc 2009;69:883-91, quiz.

21. Eckardt AJ, Swales C, Bhattacharya K, et al. Open access colonoscopy in the training setting: which factors affect patient satisfaction and pain? Endoscopy 2008;40:98-105.

22. de Jong, V, Sint Nicolaas JS, Lalor EA, et al. A prospective audit of patient experiences in colonoscopy using the Global Rating Scale: A cohort of 1,187 patients. Can J Gastroenterol 2010;24:607-13.

23. Maslekar S, Hughes M, Gardiner A, Monson JR, Duthie GS. Patient satisfaction with lower gastrointestinal endoscopy: Doctors, nurse and nonmedical endoscopists. Colorectal Dis 2010;12:1033-8.

24. Scotto F, De Ceglie A, Guerra V, Misciagna G, Pellecchia A. Determinants of patient satisfaction survey in a gastrointestinal endoscopy service. Clinical Governance: An International Journal 2009;14:86-97.

25. Yanai H, Schushan-Eisen I, Neuman S, Novis B. Patient satisfaction with endoscopy measurement and assessment. Dig Dis 2008;26:75-9.

26. Del Rio AS, Baudet JS, Fernandez OA, Morales I, Socas MR. Evaluation of patient satisfaction in gastrointestinal endoscopy. Eur J Gastroenterol Hepatol 2007;19:896-900.

27. Schoen RE, Weissfeld JL, Bowen NJ, Switzer G, Baum A. Patient satisfaction with screening flexible sigmoidoscopy. Arch Intern Med 2000;160:1790-6.

28. Schutz SM, Lee JG, Schmitt CM, Almon M, Baillie J. Clues to patient dissatisfaction with conscious sedation for colonoscopy. Am J Gastroenterol 1994;89:1476-9.

29. Yacavone RF, Locke GR III, Gostout CJ, Rockwood TH, Thieling S, Zinsmeister AR. Factors influencing patient satisfaction with GI endoscopy. Gastrointest Endosc 2001;53:703-10.

30. Tarazi EM, Philip BK. Friendliness of OR staff is top determinant of patient satisfaction with outpatient surgery. Am J Anesthesiol 1998;25:154-7. 
31. Denis B, Weiss AM, Peter A, Bottlaender J, Chiappa P. Quality assurance and gastrointestinal endoscopy: An audit of 500 colonoscopic procedures. Gastroenterol Clin Biol 2004;28:1245-55.

32. Thompson DG, Lennard-Jones JE, Evans SJ, Cowan RE, Murray RS, Wright JT. Patients appreciate premedication for endoscopy. Lancet 1980;2:469-70.

33. Pena LR, Mardini HE, Nickl NJ. Development of an instrument to assess and predict satisfaction and poor tolerance among patients undergoing endoscopic procedures. Dig Dis Sci 2005;50:1860-71.

34. Fox SA, Heritage J, Stockdale SE, Asch SM, Duan N, Reise SP. Cancer screening adherence: Does physician-patient communication matter? Patient Educ Couns 2009;75:178-84.
35. Carcaise-Edinboro P, Bradley CJ. Influence of patient-provider communication on colorectal cancer screening. Med Care 2008:46:738-45.

36. Lauver DR, Owen B, Egan J, Lovejoy LS, Henriques JB. Relationships of practitioner communications and characteristics with women's mammography use. Patient Educ Couns 2003;51:65-74.

37. Schutz SM, Lee JG, Schmitt CM, Baillie J. Patient satisfaction with conscious sedation for endoscopy. Gastrointest Endosc 1994;40:119-20.

38. Anderson C, Krska J, Murphy E, Avery A. The importance of direct patient reporting of suspected adverse drug reactions: A patient perspective. Br J Clin Pharmacol 2011; DOI:10 1111/j 1365-2125 201103990 x 2011. 


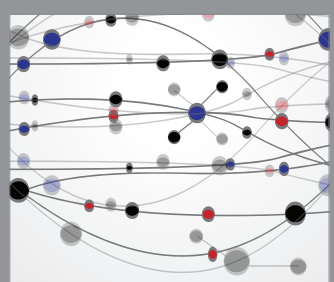

The Scientific World Journal
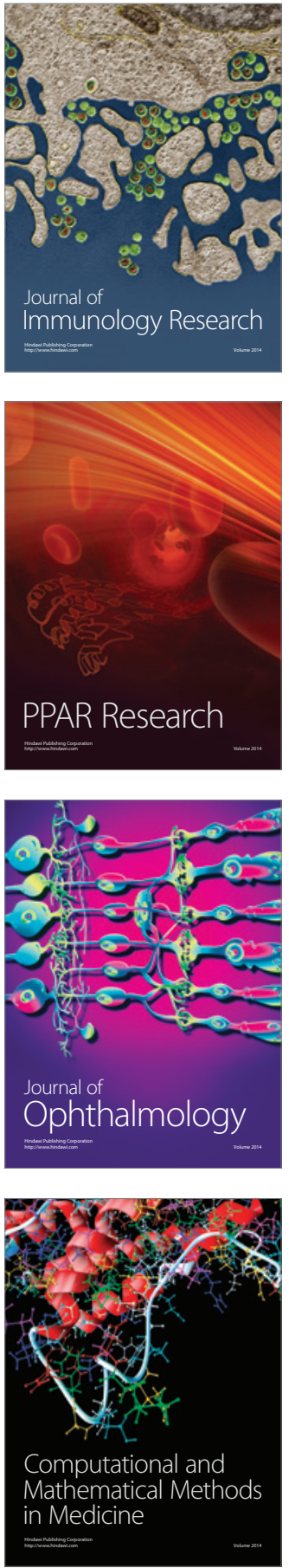

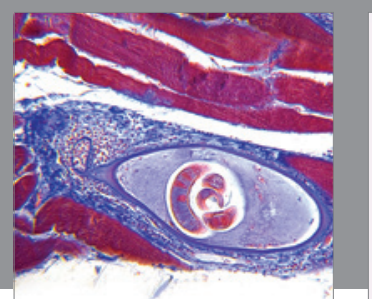

Gastroenterology Research and Practice

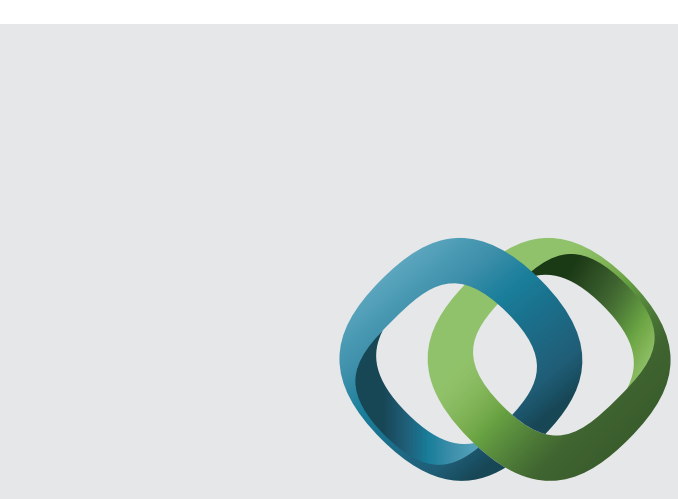

\section{Hindawi}

Submit your manuscripts at

http://www.hindawi.com
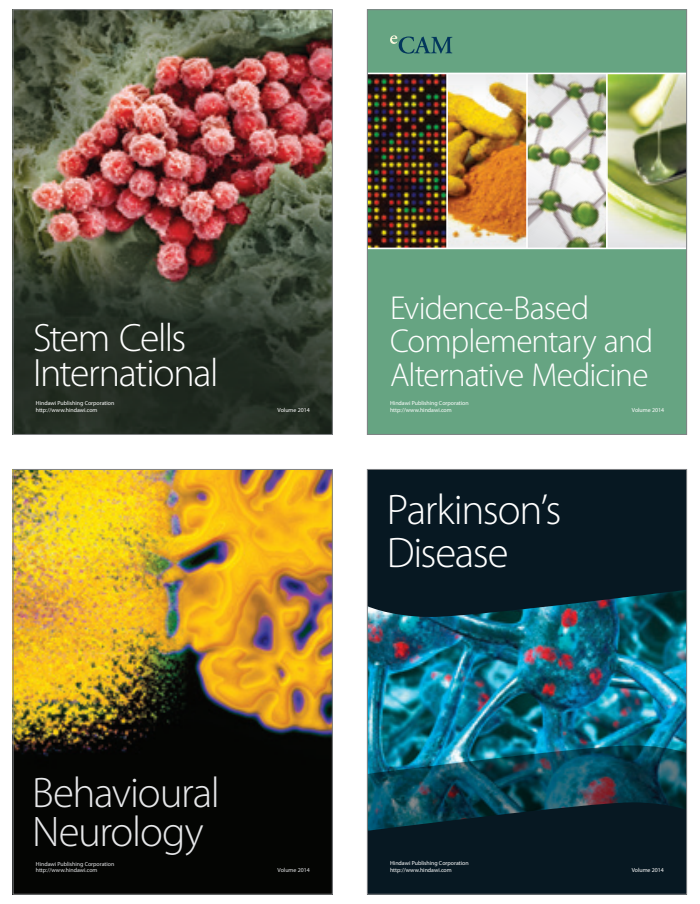
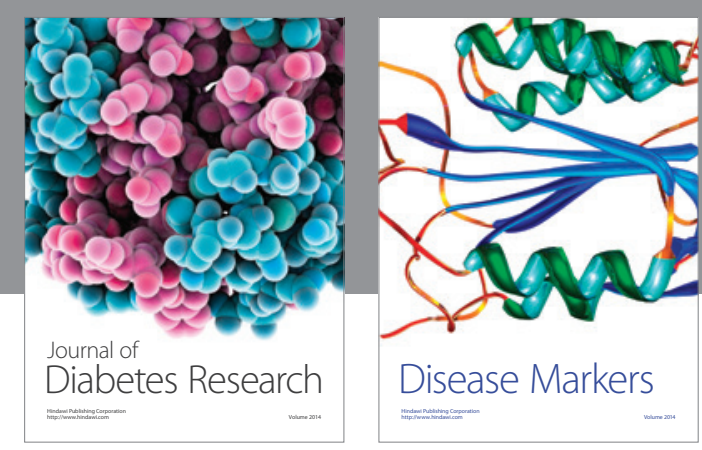

Disease Markers
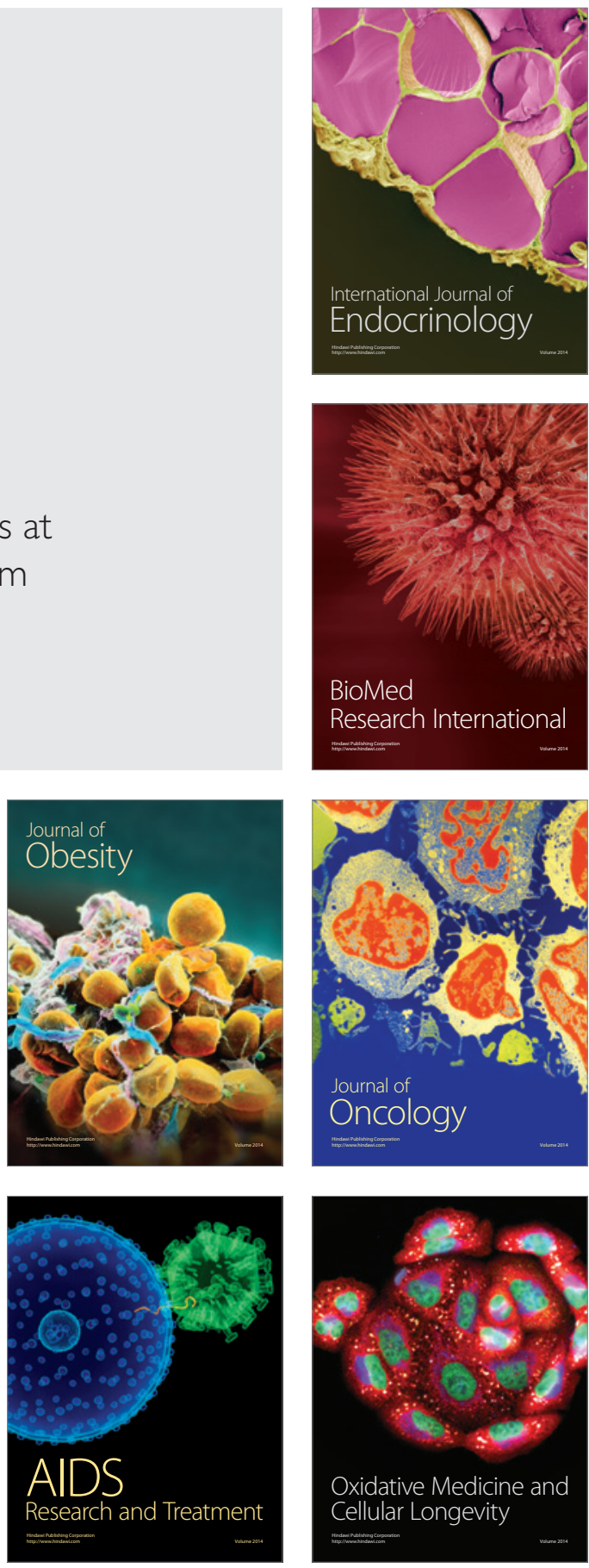